\title{
TEACHER'S PERCEPTION ON FOLKLORES IN ENGLISH TEXTBOOK IN SMA 1 BAE KUDUS
}

\author{
Riyan Dwi Cahyaningsih \\ email: cahyaningsih_dwi@yahoo.com
}

\begin{abstract}
Selection of teaching materials is one of the main important things to be done by the teacher. Through the process of selecting appropriate teaching materials, the learning process becomes successful. The importance of knowing the perception of teachers in the use of learning materials is essential known. The purpose of this research was to determine the perceptions of teachers about folklore texts in English textbook in class X SMA 1 Bae Kudus. This research is a descriptive qualitative. The instrument used was questionnaires. List of statements and questions given to teachers in class $X$ SMA 1 Bae Kudus to know the teacher's perception of the text folklore textbook graders $X$.

The results of this research, the researcher conclude that the teacher's perception is different when responding folklore text used for learning materials. X grade of English teacher there who answered "Yes" there is also answered "No" either in the statement or question given by the researcher. The answer is different because of the teacher's perception of the problems that arise in learning a skill as reading, accuracy in tapping local wisdom and meanings in folklore. Researcher advise that text folklore used in teaching students of class X are texts folklore that surrounds the student environment that has value and the message that is important to know the students and can be preserved continuously. The importance of the selection of appropriate teaching materials made in accordance with the context of the learning environment so that students will be exactly the intended target with outcomes that students can protect and preserve the folklore.
\end{abstract}

Key words: Teachers' perception, Folklores, Textbook.

\begin{abstract}
ABSTRAK
Pemilihan bahan ajar merupakan salah satu hal penting yang harus dilakukan oleh guru. Melalui proses pemilihan bahan ajar yang tepat, proses belajar menjadi sukses. Pentingnya mengetahui persepsi guru dalam penggunaan bahan ajar sangat penting diketahui. Tujuan dari penelitian ini adalah untuk mengetahui persepsi guru tentang teks cerita rakyat dalam buku teks bahasa Inggris di kelas X SMA 1 Bae Kudus. Penelitian ini bersifat deskriptif kualitatif. Instrumen yang digunakan adalah kuesioner. Daftar pernyataan dan pertanyaan yang diberikan kepada guru kelas X SMA 1 Bae Kudus untuk mengetahui persepsi guru terhadap teks cerita rakyat bahan ajar kelas X.

Hasil penelitian ini, peneliti menyimpulkan bahwa persepsi guru berbeda bila menanggapi teks cerita rakyat yang digunakan untuk materi pembelajaran. Kelas X guru bahasa Inggris ada yang menjawab "Ya" ada juga yang menjawab "Tidak" baik dalam pernyataan atau pertanyaan yang diberikan oleh peneliti. Jawabannya berbeda karena persepsi guru terhadap masalah yang timbul dalam belajar keterampilan membaca, ketepatan dalam memanfaatkan kearifan lokal dan makna dalam cerita rakyat. Peneliti menyarankan agar teks cerita rakyat yang digunakan dalam mengajar siswa kelas $\mathrm{X}$ adalah teks cerita rakyat yang mengelilingi lingkungan siswa yang memiliki nilai dan pesan yang penting untuk diketahui siswa dan dapat dipertahankan terus menerus. Pentingnya pemilihan bahan ajar yang tepat dibuat sesuai dengan konteks lingkungan belajar sehingga siswa akan tepat sasaran dengan target agar siswa dapat melindungi dan melestarikan cerita rakyat.
\end{abstract}

Kata kunci: Persepsi guru, Cerita Rakyat, Buku Teks.

\section{INTRODUCTION}

English educational objective is to develop the ability to communicate in both written and verbal. The language skills include listening, speaking, reading, and writing. The development of language skills need to be supported by an awareness of the nature and importance of English as one of the main foreign language to become a major tool of learning. However, the

106 | Jurnal Kredo

Vol. 1 No. 1 Oktober 2017 development of language without relating to culture and expand the role of language in culture will be the role of the language to be reduced.

One of the main components that determine the success of learning: the role of the book as a source of learning. The book as a reference source that can contain a variety of information that is written by the author to the reader as a step to obtain an overview of the topics 
covered at the time. The presence of books in education as one of the main sources of learning is often associated with the completeness of the textbook. Lasa (2006: 1) describes the textbook is a learning tool that is commonly used by schools and colleges to support a teaching program

The quality of a good textbook can provide insight, knowledge, and skills that are easily understood by students. Textbooks say to the area to be studied if in providing learning resources to students has been planned from the beginning by the teachers so as to present a meaningful learning process to students. Selection of the textbook is important to do because not all textbooks in line with the syllabus and basic competencies that are taught at the time. Textbooks in use in learning in high school (SMA) is determined by the teacher as presenter of learning materials that lead students toward understanding the ideal expected by the teacher. Errors in selecting appropriate textbooks resulted in the learning process is said to be less successful because the textbook can not be a source of learning. Existing demands in the syllabus and basic competence in the high school level testified that the use of textbooks in learning can come from anywhere, but the truth of the facts in terms of priority.

Textbooks can now be obtained easily, because the technology can be used by students and teachers in acquiring. Technology as a means facilitate learning becomes essential to use for access to inexpensive and can be done anywhere and is not limited by time. Through the provision of information by the use of electronic textbooks such that there is completeness of the textbook is used as a source of learning in school and as a complement to students' needs.

Folklore is one of the main stories in the English language learning in class $\mathrm{X}$ SMA. Various folklore as myths, legends, and fairy tales is a form of folklore in a story in the English textbook reading skills as learning materials. But the stories in the text students are always given the stories that are generally well known local stories not shown in the environment of students. It makes students less able to explore the folklore that exists in the environment. Sensitivity students in preserving folklore to be reduced because of the absence of regional folklore

students' place of origin contained in textbooks. Whereas folklore in the student had the noble values that can be preserved and used as one of the main ways to improve the sensitivity of students in various local cultural wealth that is in the vicinity.

Prose folklore as folklore, as stated Hutomo (1991: 7) have the feature (1) shall be oral (oral), (2) are traditional, (3) its existence often have variants or versions, (4) is always anonymous, and ( 5) tend to have a clear formula or formula (read Danandaja 2008: 58). Meanwhile, Endraswara (2009: 21) complements the characteristics of the folklore of the cover (1) have utility for supporting or collectively, (2) is pralogis, (3) become a common and shared responsibility, and (4) the nature plain and spontaneous.

Endraswara (2009: 21) further revealed that "the characteristics of folklore namely (1) shows the pragmatic aspects of folklore, (2) shows the logic of folklore which are sometimes still in its early stages pre thoughts, (3) refers to the aspect of preservation and safeguard folklore relating to collective nature, and (4) describe the presence of folklore and not necessarily intentional, and less noticeable."

Focused on these characteristics, in the realm of culture, Harvilahti (2003: 200) and Koster (1978: 42-43) states "is the work of traditional folklore that was born from the culture of the 
community. Therefore, folklore has a strong link with nature, circumstances, and the tradition of the owner of folklore. "The Brunvand (1978: 37) argues" Based on the approach anthropological folklore appeared not only a series of style abstract, verbal, or otherwise, but as traditional patterns of thought and behavior that looks at different ways of communicating."

Reading skills are skills that are given to students to explore the meaning or purpose of reading or discourse in writing so that it can obtain the information they have read something. On reading skills class X SMA 1 Bae Kudus used textbook in practice providing illustrations or folklore is still within reach in general has not shown textbook gives examples of folklore in the student environment. comprehension should show characteristic areas of excellence and become one of the main steps to foster the younger generation who know, know, and understand the folklore surrounding is reduced.

Nurhadi (1995: 340) states that in general assert reading is an interpretation of symbols written or read is to grasp the meaning of a particular sequence of letters. Reading is to identify the symbols and associate meanings. Reading can also be translated as the process of identifying and comprehension are searching messages conveyed through written language system.

The importance of providing examples of the application of learning to cultivate a sense of sensitive ,want to know, responsibility and the spirit of preserving the local culture in a neighborhood area students become characteristic each school. Research conducted by Rilya Olga (2014) titled "The Teachers' Perceptions On English As A Medium Of Instruction For Mathematics And Science". Rilya research results Olga (2014) is the importance of the use of English as the instruction in the subjects of mathematics, and science and other subjects. The importance of confidence conducted by the teacher in expressing perceptions in English would improve the ability of teachers to get information and deliver well informed. Teachers agree that the importance of learning the English language and apply it as a language of instruction in various subjects.

Based on the issues that have been submitted so in this study researchers determined the research title is "Teacher Perceptions of folklore in English Textbook in SMA 1 Bae Kudus". The study is expected to obtain information about the teacher's perception of the folklore texts used in English language learning for the benefit of this and that is therein.

\section{METHOD OF THE RESEARCH}

This research uses descriptive qualitative research. Descriptive research aims to reveal various qualitative information with the description of a careful and nuanced to describe accurately the properties of a thing, a state, a phenomenon, but not limited to data collection but include the analysis and interpretation of that data (Sutopo in the Al-Ma'ruf 2010: 83). The strategy in this research is a case study rooted, ie the qualitative research has been to determine the focus of research in the form of the main variable assessed based on the purpose and asked its writer before the writer to the field of study (Sutopo, 2006: 137).

Data is basically a raw material collected by investigators of the world had learned (Sutopo, 2006: 85). The data in this study is the perception of the teacher in SMA 1 Bae Kudus. The data source is the subject of research from which the 
data was obtained (Siswantoro, 2010: 72). Sources of primary data in this study is the teachers of English SMA 1 Bae Kudus.

After collecting the required data, the writer analyze it by coding process through the following steps.(Zacharias, 2013: 114-11)

1. The writer collected the quisionnaire sheets that have been completed by the participants.

2. Gathering the answer of the open-ended questions and making the general description about the teacher's opinion about the folklore in English textbook

3. Organizing the data gathered from the close-ended questionnaire according to each category to evaluate the teacher's perception about folklore in English textbook.

4. Putting the data into table.

5. Arriving at generalizations by making deductions.

\section{RESEARCH FINDING}

This chapter contains of explanation about the data findings of the research that consists of the result of the teacher's perceptions of folklorre in English textbook and also the discussion of data findings.

\subsection{Data Findings}

The writer serves the data of analysis that has been found from Teacher's perceptions which taken from questionnaire instrument. The questionnaire was presented to the teachers with an opportunity not only to express their problem and concerns, but also allowed them to express their idea and perceptions.

The writer divides questionnaire question become three sections. Each section distinguished grounded on some perceptions' aspects of include participants' feeling on section 1, building character 2, Reading Skill, and 3, Local wisdom.

To present the data analysis based on 3 sections as the data findings of the research, it is shown in several tables. First table (table 1) presents the analysis result of building character, Second table (table .2), next table is analyzed reading skill, and the last table (table 3) presents the analysis result of local wisdom. In section 4.3 is analyzed the summary of teachers' response from questions and it is taken into a table from 2 English teachers of SMA 1 Bae Kudus which has given reading lessons about folklore. The result quistionnaire of Teacher Perceptions on Text Folklore in the Textbook of English in SMA 1 Bae Kudus.

The results of questionnaires that have been given to teachers of English subjects in class X SMA 1 Bae Kudus during the months of January-February 2017. The perception that the teacher is focused on three things that build character through folklore texts, reading skills, local knowledge on the text of the story people.

The following table 1 . Regarding the teacher's perception of the text folklore textbook English in SMA 1 Bae Kudus.

\section{A. Building Character through Text Folklore}

Questionnaires given to teachers about building character through folklore text contains statements about folklore texts 
contained in the textbook and behavior, sensitivity, local culture be an influence on the outcome of the textbook used by teachers in teaching.

Table 4.1 Building Character

\begin{tabular}{|c|c|c|c|c|c|}
\hline \multirow[t]{2}{*}{ No. } & \multirow[t]{2}{*}{ Questions } & \multicolumn{2}{|c|}{$\begin{array}{c}\text { Participant } 1 \\
\text { Answer }\end{array}$} & \multicolumn{2}{|c|}{$\begin{array}{c}\text { Participant 2 } \\
\text { Aswer }\end{array}$} \\
\hline & & Yes & No & Yes & No \\
\hline 1. & $\begin{array}{l}\text { Text of folklore in the textbook of class } \\
X \text { contains precise readings to be given } \\
\text { to students. }\end{array}$ & $\mathrm{V}$ & & - & $\mathrm{V}$ \\
\hline 2. & $\begin{array}{l}\text { Through the use of folklore text has } \\
\text { given motivation to students in reading } \\
\text { comprehension. }\end{array}$ & $\mathrm{V}$ & & $\mathrm{V}$ & \\
\hline 3. & $\begin{array}{l}\text { Student behavior in the form of } \\
\text { sensitivity to local cultures that exist in } \\
\text { the environment of students increased } \\
\text { after the text of folklore textbook } \\
\text { studied. }\end{array}$ & $\mathrm{V}$ & & $\mathrm{v}$ & \\
\hline 4. & $\begin{array}{l}\text { The folklore text is easy to understand } \\
\text { by students to know the origin of the } \\
\text { story. }\end{array}$ & $\mathrm{V}$ & & $\mathrm{v}$ & \\
\hline 5. & $\begin{array}{l}\text { The folklore text makes pupils more } \\
\text { aware of the folklore around him. }\end{array}$ & V & & v & \\
\hline 6. & $\begin{array}{l}\text { The folklore text has similarity with the } \\
\text { folklore of the student environment. }\end{array}$ & V & - & v & - \\
\hline 7. & $\begin{array}{l}\text { The folklore text gives impact to the } \\
\text { increase of curiosity of the students } \\
\text { about the story. }\end{array}$ & & & v & \\
\hline 8. & $\begin{array}{l}\text { The folklore text includes knowledge, } \\
\text { reasoning, procedures in accordance } \\
\text { with English language learning for class } \\
\text { X. }\end{array}$ & & & v & \\
\hline 9. & $\begin{array}{l}\text { The folklore texts have similar values } \\
\text { with folklore in the students' } \\
\text { environment. }\end{array}$ & & & $\mathrm{V}$ & \\
\hline 10. & $\begin{array}{l}\text { In the folklore text, there are characters, } \\
\text { plot, conflict, meanings and values that } \\
\text { can be used as an evaluation for } \\
\text { students. }\end{array}$ & & & $\mathrm{v}$ & \\
\hline Tota & & 10 & - & 9 & 1 \\
\hline
\end{tabular}


Based on table 1 and table 2 on questionnaires given to teachers about building character through folklore texts are divided into some kind of statement that is associated with the text of folklore in textbooks and student behavior related to sensitivity to local culture. There are ten statements given writer to both teachers of English subjects in class $\mathrm{X}$ SMA 1 Bae Kudus. Both informants provide different statements on points the first questioner statement that "1) the text of folklore in the textbook of class $X$ contains precise readings to be given to students". The first informant stated folklore texts used to teach contain appropriate reading for students of class $\mathrm{X}$ while the second informant stated readings given to students is still not appropriate to be given to students of class $\mathrm{X}$. In the statement number from 2 to 10 two teachers have the same answer that answered "Yes" to all statements. This indicator shows the perception of teachers towards learning English subjects in class X to be more open, it means teachers perspectives and perceptions are almost identical to the text of folklore and behaviors that arise after the use of textbooks.
Based on the explanation can be concluded the folklore used in English learning class X SMA 1 Bae Kudus still not appropriate used for learning. Text folklore has not been functioning as reading material that is able to build the character of students through reading the text of folklore. These findings indicate that it is important to provide appropriate folklore texts for students of class X. The existing findings in research on building character through text folklore as follows:

a) The text of folklore is still not suitable for students of class X.

b) The text of folklore are still not able to build the character of students of class $\mathrm{X}$.

c) Text folklore still use the same story from the previous year were not there in the student environment.

\section{B. Reading Skill}

The second questioner about the reading skills of students associated with the use of folklore texts given to the students. These questionnaires are given to teachers of English subjects in class X SMA 1 Bae Kudus.

Table 4.2 Reading Skill

\begin{tabular}{|c|c|c|c|c|c|}
\hline \multirow[t]{3}{*}{ No. } & \multirow[t]{3}{*}{ Question } & \multirow{2}{*}{\multicolumn{2}{|c|}{$\begin{array}{c}\text { Participant } \\
1 \\
\text { Answer } \\
\end{array}$}} & \multirow{2}{*}{\multicolumn{2}{|c|}{$\begin{array}{c}\text { Participan } \\
2 \\
\text { Answer }\end{array}$}} \\
\hline & & & & & \\
\hline & & Yes & No & Yes & No \\
\hline 1. & $\begin{array}{l}\text { The text of folklore can be used for } \\
\text { improving reading skills of class } \mathrm{X} \\
\text { appropriately }\end{array}$ & V & & V & \\
\hline 2. & $\begin{array}{l}\text { The text of folklore can improve } \\
\text { critical reading skills for students of } \\
\text { class X. }\end{array}$ & $\mathrm{v}$ & & $\mathrm{v}$ & \\
\hline
\end{tabular}




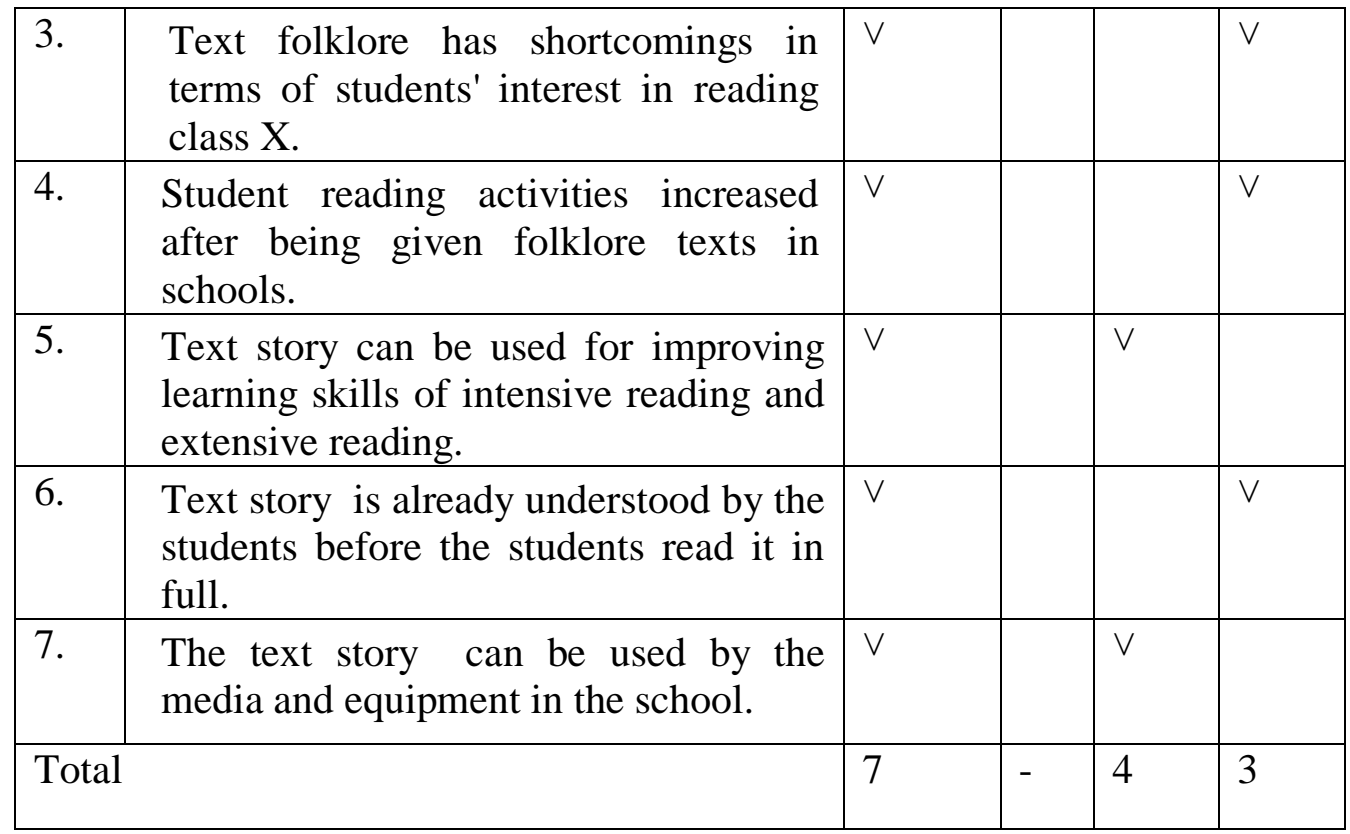

Based on table 2 on the reading skills of students of folklore texts stimuli given to the subject teachers of English class X SMA 1 Bae Kudus then there is a different result from the administration of the questioner. The first informant or an English teacher stated that the seven components of the statement given by the writer are answered "Yes". The answer is a writer statement about the completeness and accuracy of folklore texts in the textbook for students of class X SMA 1 Bae Kudus. The second informant is subject teachers of English class X declared perceptions through different answer is to answer "yes" four statements and answer "No" three statements.

Based on the summary, there are several shortcomings that become an obstacle in terms of understanding and activity of students in the study of folklore texts. The findings obtained from this study regarding the students' reading skills through learning using folklore text is as follows:

a) Low interest due to the students' reading text stories used in the learning has not had its own uniqueness and attractiveness.

b) Sensitivity of students to the local culture is still increasing due to the lack of text folklore are on the stories in the student environment.

c) The text of folklore has not shown material which is able to be easily understood by the students so that students are difficult to understand.

\section{The Local Wisdom of the Text Folklore}

Local wisdom in folklore texts given by the writer to teachers in class X SMA 1 Bae Kudus are given through the form of questionnaires. The questioner expected to answer statements regarding the clarity of local wisdom in folklore texts. 
Table 4.3 Local Wisdom

\begin{tabular}{|c|c|c|c|c|c|}
\hline \multirow[t]{2}{*}{ No. } & \multirow[t]{3}{*}{ Question } & \multirow{2}{*}{\multicolumn{2}{|c|}{ Participant 1}} & \multirow{2}{*}{\multicolumn{2}{|c|}{$\begin{array}{c}\text { Participant } \\
2 \\
\text { Answer }\end{array}$}} \\
\hline & & AI & & & \\
\hline 1 & & Yes & No & $\frac{\text { Yes }}{\mathrm{V}}$ & No \\
\hline 1. & $\begin{array}{l}\text { 1he lolkiore text contains local } \\
\text { wisdom in the student environment. }\end{array}$ & & & & \\
\hline 2. & $\begin{array}{l}\text { The text folklore is associated with } \\
\text { wisdom in the student environment. }\end{array}$ & V & & V & \\
\hline 3. & $\begin{array}{l}\text { Students may make observations as } \\
\text { folklore textbook exists in the } \\
\text { student environment. }\end{array}$ & $\mathrm{V}$ & & $\mathrm{V}$ & \\
\hline 4. & $\begin{array}{l}\text { The text of folklore can be given } \\
\text { real example because it happened } \\
\text { in the student environment. }\end{array}$ & V & & V & \\
\hline \multicolumn{2}{|l|}{ Total } & 4 & & 4 & \\
\hline
\end{tabular}

Based on table 3 of the local wisdom in folklore texts given by teachers from the selection of textbooks used may be explained that the teachers have the same perception of the statements given to both teachers'. The two teachers agree to give an answer "Yes" from the four statements there.

\section{Instruments About Perception Teachers Against Text Folklore}

In this type of open-closed questionnaire, the writer gave the questions related to the text folklore, existing deficiencies in the text of folklore, student motivation in learning, values, mandate, additional materials other than text folklore, and move text preservation of folklore. The results obtained show that the answer varies with differences in perception between subject teachers. The results of the questionnaires can be seen in full in Appendix

\subsection{The Summary of Questionnaire Result}

In this section the writer explains the summary of results of questionnaires that have been given to the subject teachers of English class X on " Teachers Perceptions of Folklore in the English Textbook in SMA 1 Bae Kudus".

The questioner is divided into two kinds of questionnaires are closed and sealed open. On the results of the closed first questioner, data questionnaires which showed the level of building character through text folklore through textbooks are in accordance with the direction of learning. However, there are several trends that differ from the results of questionnaires, ie at the first question is "Text folklore in the textbook of class $\mathrm{X}$ contains precise readings to be given to students". The first informant providing 
answers "Yes", while the second informant gives the answer "No. Description of the impact of widespread because based on the answers that have been given then there needs to be clarity about the folklore texts used for teaching English subjects covered in class X. The second questioner on the skills of reading, which is obtained answers to questionnaires that vary or differ from informants 1 and the informant 2. this difference has been entered at the level of implementation of a learning with the development of folklore texts as a learning material with finesse students in improving their reading skills. A third questioner about the local wisdom in folklore texts with answers informant informant 1 and 2 have the same perception of the local wisdom in folklore texts that are used for learning materials.

The results of the second questioner that kind of questionnaires closed open showing different data between the informant and the informant 12 . This is an answer that shows teachers' perceptions about the process, implementation, and results that pleases performed using different steps. Each teacher has a characteristic or a different way of teaching that although the text of folklore are used for the same learning. The absence of folklore texts containing local wisdom in Kudus district is one of the main facts found in textbooks of English class X SMA 1 Bae Kudus. This was disclosed by the informant when the researchers gave questionnaires.

Based on the findings of the first and second questioner that has been described, it can be concluded that the perception of teachers of

114 | Jurnal Kredo Vol. 1 No. 1 Oktober 2017 folklore in English textbook in class $X$ SMA 1 Bae Kudus as follows:

1. Text folklore that has been used so far has not demonstrated the characteristics of the local culture in Kudus and surroundings.

2. The student has not reacted active, responsive, and less concerned with the story of the people around him.

3. There is no text selection story that really has value and mandate that can be taken by students after given text folklore.

4. Text folklore is still concentrated in the textbook monotonous and there is no other development in learning.

\section{DISCUSSION}

The discussion in this chapter explains the teacher's perception on Text Folklore in the English Textbook of SMA 1 Bae Kudus. This perception is based on the analysis of questionnaires which writer have given to teachers with a statement of criteria ranging from building character through folklore texts, reading skills, local wisdom on the folklore text and Teacher Perceptions on Folklore text.

\subsection{Building Character}

In this part, the writer focuses on building character of the students that they use in improving their motivation for reading text of folklore and to increase of curiousity of the student's about story based on the data result of the study. take 
points of view the data result as follows:

1.The accuracy of the folklore text

At this point accuracy folklore texts for students of classes $\mathrm{X}$ becomes important to know. Through the accuracy of the text of the obtained accuracy of textbook used in teaching.

2. Motivation

Folklore text used in the study had high motivation and stimulation for students to learn. This motivation can be either the preservation of folklore texts, interest in folklore texts, and enthusiasm in learning about the folklore texts that exist in the student environment.

3. Cultivation of character through student behavior

Characters in the text of folklore can serve as benchmarks in the attractiveness and accuracy of readings given to the students. Through the cultivation of the characters in the text folklore student behavior will be more developed and able to generate positive behaviors.

4. Folklore text that is easily recognizable for students

Folklore text used in the study is the text of folklore in the environment of the student so that students increasingly understand that in the neighborhood there is a folklore that it is important to be preserved and known by the students.
5. Curiosity

Text of folklore has curiosity and be a positive stimulus for students to further explore the folklore that exist in the environment.

\subsection{Reading Skill}

In this part, the writer focuses on reading skill of the students that they use in improving their critical reading text of folklore and improving learning skills of intensive reading and extensive reading based on the data result of the study. Take points of view the data result as follows:

\section{Interest in Reading}

Through folklore texts can increase students' interest in reading for the better. Interest in reading can be tapped via text folklore and able to change students' views on the text of folklore into text favored by students.

\section{Reading Activities}

The favorite of students in reading can be increased and is able to activate the students in reading

\subsection{Local Wisdom on Folklore Text}

In this part, the writer focuses on local wisdom on folklore text, based on the data result of the study, the researcher take points of view the data result as follows:

1. Local wisdom

Folklore Text used in learning to know the students' local wisdom in the student environment. Local wisdom is what is important to know and later became a regional identifier, 
so that students are proud of the environment he knows.

\section{Environment Students}

Folklore text describes the environment of students who are folklore, so that students can make direct observations of the origins of folklore.

\section{REFERENCE}

Al-Ma'ruf, Ali Imron. 2010. Kajian Stilistika Perspektif Kritik Holistik. Surakarta: UNS Press.

Andayani. 2008. Bunga Rampai Model-Model Pembelajaran Bahasa, Sastra, dan Seni: Relevansi Integrated Approach dengan Pembelajaran Bahasa Indonesia. Yogyakarta: Mata Pdi Presindo.

Anderson, C. W., \& Roth, K. L. 1991. Science teachers' conceptions of teaching and learning. Greenwich: JAI Press.

Bandura, A. 1995. Self-Efficacy in Changing Societies. Cambridge: Cambridge University Press.

Hamid Darmadi. 2011. Metode Penelitian Pendidikan. Bandung: Alfabeta.

Danandjaja, James. 1994. Folklor Indonesia: Ilmu Gosip, Dongeng, dan lain-lain. Jakarta: Grafiti.

Danandjaja, James. 1995. "A Comparative Study of Japanese and Indonesian Folklores”. Southeast Asian Studies, Vol. 33, No. 3, Desember. pg. 484-496.

Danandaja, James. 2008. "Pendekatan Folklor dalam Penelitian Bahan-Bahan Tradisi Lisan" dalam Pudentia MPSS (Ed.) Metodologi Kajian Tradisi Lisan. Jakarta: Asosiasi Tradisi Lisan.

Dopo Ferdinandus Bate, Ismaniati Christina. 2015. Persepsi Guru Tentang Digital Natives, Sumber Belajar Digital dan Motivasi Memanfaatkan Sumber Belajar Digital. Jurnal Inovasi dan Teknologi Pendidikan. Program Studi Teknologi Pembelajaran PPs UNY: Yogyakarta. Diakses hari selasa 13 Desember 2016.

Endraswara, Suwardi. 2009. Metodologi Penelitian Folklor: Konsep, Teori, dan Aplikasi. Jakarta: Medpress.

Goker, S. D. 2006. Impact of peer coaching on self-efficacy and instructional skills in TEFL teacher education. System. Vol. 34, 239-254.

116 | Jurnal Kredo

Vol. 1 No. 1 Oktober 2017 
Hsieh, H. 2002. Teachers' Beliefs about English Learning: A Case Study of Elementary School English Teachers in Taipei Country. Unpublished master thesis. Taipei: National Taipei Teachers" College.

Hutomo, Suripan Sadi. 1991. Mutiara Yang Terlupakan: Pengantar Studi Sastra Lisan. Surabaya: HISKI.

Harvilahti, Lauri. 2003. Folklore and Oral Tradition. Helsinki: Finnish Literature Society.

Jia, Y. 2004. ESL teachers' perceptions and factors influencing their use of classroom-based reading assessment. Bilingual Research Journal, Vol. 29(2), 459-482.

Koster, G.L. 1978. "Kaca Mata Hitam Pak Mahmud Wahid atau Bagaimanakah Meneliti Puitika Sebuah Sastra Lisan" dalam Pudentia MPSS (Ed.) Metodologi Kajian Tradisi Lisan. Jakarta: Yayasan Obor Indonesia dan Yayasan Asosiasi Tradisi Lisan.

Koentjaraningrat. 1994. Kebudayaan Mentalitas dan Pembangunan. Jakarta: Gramedia Pustaka Utama.

Lasa, H. S. 2006. "Penulisan Buku Teks Perguruan Tinggi” (Online) dalam http:/lib.ugm.ac.id. Diakses tanggal 13 Desember 2016.

Mardalis. 2008. Metode Penelitian Suatu Pendekatan Proposal. Jakarta: Bumi Aksara

Miles, B.B., dan A.M. Huberman. 1992. Analisa Data Kualitatif. UI Press Jakarta.

Moloi, L. 2009. Exploring the perceptions of English second language teachers about leaner self-assessment in the secondary school. (Master"s thesis, University of Pretoria) Retrieved from http://upetd.up.ac.za/thesis/available/etd09082009144620/unrestricted/dise rtation.pdf. Diakses tanggal 13 Desember 2016.

Moleong, Lexy J. 1994. Metodologi Penelitian Kualitatif. Bandung: Remaja Rosdakarya.

Musclich, Masnur. 2010. Text Book: Dasar-dasar Pemahaman, Penulisan, dan Pemakaian Buku Teks. Yogyakarta: Ar-Ruzz Media.

Pannen, P. dan Purwanto. 2001. Penulisan Bahan Ajar. Jakarta: PAU-PPAI. Universitas Terbuka. 
Rilya Olga. 2014. The Teachers' Perceptions On English As A Medium Of Instruction For Mathematics And Science. Skripsi. Universitas Muria Kudus: Kudus.

Richards, J., and D. Mahoney .1996. Teachers and Textbooks: A Survey of Beliefs and Practices, in Perspectives. Working Papers (City University of Hong Kong, Department ocfoEmnmgliitstho) u8(s1er),40-61.

Rahmanto, B. \& B. Kaswanti Purwo. 1999. Sastra Lihan: Pemahaman dan Interpretasi (Pilihan Karangan dalam Basis 1987-1995). Jakarta: Mega Media Abadi.

Rampan, Korrie Layun. 2014. Teknik Menulis Cerita Rakyat. Bandung: Yrama Widya.

Ratna, Nyoman Kutha. 2011. Antropologi Sastra: Peranan Unsur-unsur Kebudayaan dalam Proses Kreatif. Yogyakarta: Pustaka Pelajar.

Robson, J. 2002. The Voices of Vocational Teachers in the UK: Their Perceptions of the Nature and Status of the Further Education Teacher"s Professional Knowledge. Australian and New Zealand Journal of Vocational Education Research, Vol. 10(2), 95-113. Diakses tanggal 13 Desember 2016.

Santoso Djoko, Niken Ayu Larasati, Ramlan Arief Fathony. 2013. Persepsi Guru Pembimbing Terhadap Proses Pembelajaran Mahasiswa PPL UNY Di SMK Kota Yogyakarta Tahun Ajaran 2012/2013. Jurnal Pendidikan Teknologi dan Kejuruan, Volume 21, Nomor 4. Universitas Negeri Yogyakarta: Yogyakarta. Diakses tanggal 13 Desember 2016.

Subagyo, Amat Komari dan Aris Fajar Pambudi. 2015. Persepsi Guru Pendidikan Jasmani Sekolah Dasar terhadap Pendekatan Tematik Integratif pada Kurikulum 2013. Jurnal Pendidikan Jasmani Indonesia Volume 11, Nomor 1. Universitas Negeri Yogyakarta: Yogyakarta. Diakses tanggal 13 Desember 2016.

Sutopo, H.B. 2006. Metodologi Penelitian Kualitatif, Dasar Teori dan Terapannya dalam Penelitian. Surakarta: Universitas Sebelas Maret Press.

Siswantoro. 2010. Metode Penelitian Sastra Analisis Struktur Puisi. Yogyakarta: Pustaka Pelajar.

Subroto, Edi. 2007. Pengantar Metode Penelitian Linguistik Struktural. Surakarta: UNS Pres.

Sudjiman, Panuti. 1984. Kamus Istilah Sastra. Jakarta: Gramedia. 
Sugiarto, Eko. 2015. Mengenal Sastra Lama: Jenis, Definisi, Sejarah, dan Contoh. Yogyakarta: Andi Offset.

Soetarno. 2008. Peristiwa Sastra Melayu Lama. Surakarta: Widya Duta Grafika.

Sia, A. P. (1992). Pre-service elementary teachers' perceived efficacy in teaching environmental education: a preliminary study. Paper presented at the Annual Meeting of the North American Association for Environmental Education. Vol. 34. Diakses tanggal 13 Desember 2016.

Tarigan, Henry Guntur dan Tarigan, Djago. 2009. Telaah Buku Teks Bahasa Indonesia. Bandung: Angkasa.

Wahyuni Lilik, Endang Sumarti, dan Rokhyanto. 2015 Buku Ajar Bahasa Indonesia Berbasis Jender sebagai Media Pengembangan Karakter Siswa. Jurnal LITERA, Volume 14, Nomor 2. Universitas Negeri Yogyakarta: Yogyakarta. Diakses tanggal 13 Desember 2016 